\title{
PENGUATAN KELEMBAGAAN DAN DESTINASI DESA WISATA TAPAK TILAS SULTAN AGUNG, MANGUNAN
}

\author{
Tanto Lailam ${ }^{1}$, Awang Daru Murti ${ }^{2}$, Ani Yunita ${ }^{3}$ \\ ${ }^{1}$ Fakultas Hukum Universitas Muhammadiyah Yogyakarta. Jalan Brawijaya, Tamantirto, Kasihan, Bantul \\ DIY. E-mail: tanto.tatanegara@gmail.com \\ ${ }^{2}$ Fakultas Sosial dan Politik Universitas Muhammadiyah Yogyakarta. Jalan Brawijaya, Tamantirto, \\ Kasihan, Bantul DIY. E-mail: awang.darumurti@yahoo.co.id \\ ${ }^{3}$ Fakultas Hukum Universitas Muhammadiyah Yogyakarta. Jalan Brawijaya, Tamantirto, Kasihan, Bantul \\ $D I Y$. \\ Email: aniyunita@umy.ac.id
}

\begin{abstract}
Abstrak
Program pengabdian dengan skema Program Pengembangan Desa Mitra (PPDM) ini dilakukan untuk memperkuat kelembagaan pengelola desa wisata dan destinasi di Desa Wisata Tapak Tilas Sultan Agung, Mangunan. Tujuan program ini adalah menjadikan mitra sebagai model pusat pertumbuhan ekonomi kerakyatan dan kesejahteraan masyarakat berkelanjutan melalui pengembangan potensi desa wisata yang dipadukan dengan budaya dengan pendekatan community based tourism. Metode pelaksanaan dilakukan dengan: survei dan wawancara, focus group discussion, pelatihan, pendampingan, dan fasilitasi.Hasil Pengabdian berupa penguatan kelembagaan dan destinasi Desa Wisata Tapak Tilas Sultan Agung Mangunan dilakukan dengan melakukan pemetaan potensi unggulan daya tarik wisata melalui survei dan wawancara. Setelah dipetakan secara baik, tentu dilakukan penguatan berkaitan dengan kelembagaan dan sumber daya manusia pengelola desa wisata melalui berbagai pelatihan yang diselenggarakan, yaitu: pelatihan manajemen kelembagaan desa wisata dan community based tourism, pelatihan komunikasi pariwisata, komunikasi pemasaran dan "branding desa wisata", pelatihan pelayanan prima desa wisata, pelatihan best practice dan studi banding pengelolaan desa wisata ke Desa Wisata Nglanggeran dan Desa Wisata Bleberan. Selain itu, dilakukan penguatan destinasi di Desa wisata Tapak Tilas Sultan Agung dilakukan dengan menambahkan wisata agro berupa pemberian bibit kopi, penyediaan papan informasi daya tarik wisata yang ditempatkan pada daya tarik wisata wayu goyang, dan fasilitasi legalisasi perkumpulan seni budaya dengan pembuatan akta notaris.
\end{abstract}

Kata Kunci: Desa Wisata, Tapak Tilas Sultan Agung, Destinasi Wisata, Manajemen Kelembagaan.

\section{PENDAHULUAN}

Otonomi desa bukan sebuah kedaulatan melainkan pengakuan adanya hak untuk mengatur urusan rumah tangganya sendiri dengan dasar prakarsa dari masyarakat. Otonomi desa telah ada sejak desa itu mulai ada, dan bukan merupakan sebuah limpahan wewenang dari Negara (Sakinah Nadir, 2013: 89). Otonomi dapat menutup pintu intervensi institusi dan sebaliknya tidak dibenarkan proses intervensi yang serba paksa, mendadak dan tidak melihat realitas komunitas masyarakat desa (Dadang Juliantara, 2003: 181). Secara sosiologis yang paling berperan adalah struktur yang dibentuk oleh relasi antar warga (horisontal) dan antara warga dengan perangkat desa (vertikal) yang bersimpul pada Pemerintah Desa dan dipimpin oleh Kepala Desa/ Lurah Desa (Zen Zanibar, 2007, 186). Intinya bahwa otonomi desa adalah sebuah agenda besar yang mengarahkan Desa Mangunan menjadi lebih demokratis, mandiri dan sejahtera. Untuk itu, pembangunan desa dan pemberdayaan masyarakat desa berdasarkan prakarsa masyarakat, hak asal usul, dan adat istiadat desa sangat penting dilakukan. Salah satu pemberdayaan yang dilakukan saat ini ialah pembangunan desa wisata berbasis masyarakat yang bertujuan untuk meningkatkan kesejahteraan masyarakat Desa Mangunan dan kualitas hidup manusia serta penanggulangan kemiskinan melalui pemenuhan kebutuhan dasar, pembangunan sarana dan prasarana desa, pengembangan potensi ekonomi lokal, serta pemanfaatan sumber daya alam dan lingkungan secara berkelanjutan.

Desa wisata merupakan suatu wilayah pedesaan yang menawarkan keaslian baik dari segi sosial budaya, adat istiadat, keseharian, arsitektur tradisional maupun struktur tata ruang desa yang disajikan dalam suatu bentuk integrasi komponen pariwisata antara lain atraksi, akomodasi dan fasilitas pendukung (Yusuf Adam Hilman, 2016:5). Hal ini berarti bahwa desa wisata merupakan suatu bentuk integrasi antara atraksi, akomodasi dan fasilitas pendukung yang disajikan dalam suatu struktur kehidupan masyarakat yang menyatu dengan tata cara dan tradisi yang berlaku (nilai-nilai kearifan lokal). Unsur pengetahuan dan kemampuan lokal serta kearifan lokal yang dimiliki oleh masyarakat merupakan esensi desa wisata. Desa Wisata yang mengedepankan suasana keaslian desa 
memerlukan suatu pemahaman tentang karakter dan unsur-unsur yang ada di dalam desa (Eko Murdiyanto, 2011: 91).

Sama halnya dengan desa wisata di Desa Mangunan, berbagai ketertarikan alam, budaya asli dan kearifan lokal menyebar diseluruh desa wisata dan desa wisata tersebut dikelola secara mandiri berbasis masyarakat dari pendirian hingga saat ini, dengan modal dan pengelolaan dari masyarakat di desa wisata tersebut. Desa wisata mangunan merupakan salah satu bentuk penerapan pembangunan pariwisata berbasis masyarakat. Masyarakat lokal berperan penting dalam pengembangan desa wisata karena sumber daya dan keunikan tradisi dan budaya yang melekat pada komunitas tersebut. Di lain pihak, komunitas lokal yang tumbuh dan hidup berdampingan dengan suatu objek wisata menjadi bagian dari sistem ekologi yang saling kait mengait. Keberhasilan pengembangan desa wisata tergantung pada tingkat penerimaan dan dukungan masyarakat lokal (Made Heny, dkk, 2013: 132)

Salah satu desa wisata yang berada di Desa Mangunan yang dikelola masyarakat adalah Desa Wisata Tapak Tilas Sultan Agung. Desa wisata Tapak Tilas Sultan Agung terletak di dusun Cempluk, Daya tarik wisata sangat banyak, baik wisata alam watu goyang, wisata budaya, dan kuliner. Desa wisata ini dikelola oleh masyarakat lokal dengan pendekatan comminity based tourisme, namun dalam pelaksanaanya terutama dalam manajemen kelembagaan dan sumber daya manusia belum sesuai dengan kualitas pelayanan desa wisata yang baik dan berkelanjutan. Untuk itu program pemberdayaan masyarakat melalui Program Pengembangan Desa Mitra (PPDM) ini dilakukan.

\section{A. Tujuan Program}

Tujuan program ini adalah menjadikan mitra sebagai model pusat pertumbuhan ekonomi kerakyatan dan kesejahteraan masyarakat berkelanjutan melalui potensi desa wisata yang dipadukan dengan budaya (wisata alam, wisata kerajinan, dan budaya). Dalam arti pemberdayaan masyarakat (partisipasi aktif) sebagai inti gerakannya, dengan menempatkan mitra sebagai pelaku utama pada setiap tahapan perencanaan, pelaksanaan, dan monitoring - evaluasi program.
Pendekatan pemberdayaan (partisipasi aktif) dalam pengabdian ini berprinsip pada kemandirian masyarakat, metode ini bertujuan untuk meningkatkan kapasitas masyarakat dan menguatkan perekonomian lokal bidang pariwisata (community based tourism).

\section{METODE PELAKSANAAN}

Pemberdayaan masyarakat adalah suatu proses dimana masyarakat, terutama mereka yang miskin sumber daya, kaum perempuan dan kelompok yang terabaikan lainnya di lokasi dusun - desa wisata didukung agar mampu meningkatkan kesejahteraannya secara mandiri. Dalam proses ini, lembaga berperan sebagai fasilitator yang mendampingi proses pemberdayaan masyarakat, yang pada prinsipnya masyarakatlah yang menjadi aktor dan penentu pembangunan desa wisata, baik pembangunan atraksiakomodasi dan fasilitasi desa wisata, kelembagaan pariwisata, promosi dan komunikasi pemasaran, serta usaha berbasis masyarakat. Usulan-usulan masyarakat merupakan dasar bagi program pembangunan desa wisata. Aspek penting dalam suatu program perberdayaan masyarakat adalah: program yang disusun sendiri oleh masyarakat, menjawab kebutuhan dasar masyarakat, mendukung keterlibatan, dibangun dari sumberdaya lokal, penguatan nilai-nilai budaya setempat, memperhatikan dampak lingkungan, tidak menciptakan ketergantungan, berbagai pihak terkait terlibat, serta berkelanjutan.

Beberapa metode yang digunakan dalam pemberdayaan masyarakat ini:

1. Survei dan wawancara. Survei dan wawancara ini dilakukan untuk melihat perkembangan potensi wisata yang telah dikembangkan sebelumnya, sekaligus melihat potensi inovasi yang akan dikembangkan oleh pengelola desa wisata.

2. FGD. FGD difungsikan sebagai ajang diskusi berkaitan dengan persoalan-persoalan Desa wisata, sekaligus mencari solusi terhadap persoalan tersebut.

3. Pelatihan. Metode pelatihan dilakukan untuk mengurangi persoalan ketiadaan regulasi dan pedoman tata kelola, pengetahuan dan kekurangpahaman pengelola desa wisata (sumber daya manusia/ mitra) terhadap manajemen tata 
kelola, SDM, dan pemasaran - komunikasi pariwisata. Program-program pelatihan dalam pengabdian masyarakat dikembangkan dengan metode yang lebih sederhana, yaitu dengan menyelenggarakan sarasehan dan diskusi santai/ informal sehingga masyarakat tidak terlalu berat dalam menerima materi-materi pelatihan. Pelatihan yang dilakukan adalah pelatihan yang berkaitan dengan ruang lingkup pariwisata (pelatihan kepariwisataan) baik bersifat regulatif, manajemen tata kelola, maupun komunikasi pemasaran (Hendrie Ajie Kuncoro dan Janianton Damanik, 2002, 109). Materi-materi pelatihan yang disampaikan mengambil beberapa kasus dan best practice pengelolaan desa wisata, sehingga peserta pelatihan akan memperoleh gambaran-gambaran kasus dan strategi yang seharusnya dilakukan. Selain itu, juga sharing pengalaman merupakan syarat untuk dapat meningkatkan kreativitas dan inovasi masyarakat dan menjadi penentu pelaksanaan kegiatan dalam menciptakan masyarakat yang mandiri kompetitif berdaya saing (Kesi Widjajanti, 2011:25). Metode pelatihan dengan diskusi informal bertujuan untuk mendorong partisipasi dan perhatian peserta yang lebih intens (Bevaola Kusumasari dan Hempri Suyatna, 2015: 21).

4. Pendampingan. Untuk memastikan bahwa program-program pelatihan dapat berkelanjutan, tim pengabdian juga melakukan kegiatan pendampingan dengan pemonitoran dan evaluasi secara rutin. Dalam proses pendampingan ini, tim asistensi juga memberikan solusi-solusi atas hambatan yang dihadapi oleh masyarakat. Pendampingan ini dilakukan agar program dapat terlaksana dengan baik atau merupakan penerapan hasil pelatihan yang dilakukan. Terutama berkaitan dengan usaha berbasis masyarakat, untuk mendukung bentuk keterlibatan masyarakat tersebut adalah penyediaan fasilitas akomodasi berupa rumah-rumah penduduk (homestay), penyediaan kebutuhan konsumsi wisatawan, pemandu wisata, penyediaan transportasi lokal, pertunjukan kesenian, dan lain-lain.
5. Fasilitasi. Fasilitasi berkaitan dengan pemberian atau mempermudah akses terhadap upaya Desa Wisata untuk melakukan legalisasi kelembagaan.

Selain metode diatas, mitra juga dapat melakukan konsultasi dengan tim pengabdian atau ahliahli tertentu dengan difasilitasi oleh tim pengabdi. Untuk melengkapi metode tersebut, juga dilakukan praktek lapangan dengan melakukan studi banding pengelolaan desa wisata di daerah lain, pada pelaku usaha tertentu, dan lainnya. Studi banding ini dilakukan untuk membuat desain desa wisata (mitra) yang unggul, kompetitif dan berbudaya.

\section{PEMBAHASAN}

\section{A. Potensi Desa Wisata}

Desa Wisata Tapak Tilas Sultan Agung memiliki banyak potensi, baik wisata alam, wisata budaya, maupun wisata buatan. Potensi terbesar adalah wisata alam watu goyang (Batu goyang). Batu ini berada di wilayah Pedukuhan Cempluk sebelah Barat daya di bukit yang cukup tinggi, konon menurut cerita rakyat, bahwa batu itu untuk hinggap burung merak sebagai petunjuk keberadaan tanah yang berbau harum. Selain itu, wisata alam yang banyak dikunjungi adalah: Mata Air Bengkung, Watu Simangu, dan Watu Pengilon. Sementara wisata budaya yang menjadi keunikan Desa wisata adalah: Wisata Budaya, Karawitan Ngudiwiromo, Kethoprak Mudo Budoyo, Seni Tari Lestari Budaya, Jathilan Mudo Esthi Tomo, Wayang Kulit Ngesti Budoyo, Gejok lesung Laras budoyo, Sholawat Nabi. Terdapat juga wisata sejarah dan benda kuno yang merupakan koleksi salah satu pengelola desa wisata.

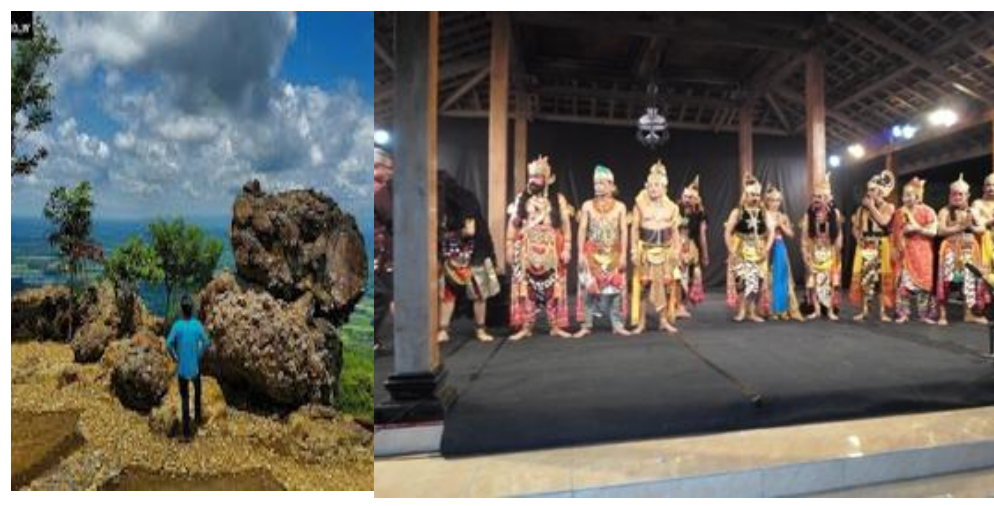

Gambar 1. Daya Tarik Wisata di Desa Wisata Tapak Tilas Sultan Agung 


\section{B. Strategi Pengembangan Wisata}

Strategi pengembangan wisata dilakukan setelah adanya hasil potensi desa wisata yang hendak dikembangkan. Strategi pengembangan wisata tersebut meliputi:

\section{Pelatihan Manajemen Kelembagaan Desa Wisata dan Community Based Tourism}

Manajemen Kelembagaan dan manajemen pengelolaan desa wisata ini menjadi sangat penting, mengingat kelembagaan dan manajemen pengelolaan desa wisata merupakan kunci sukses pengembangan desa wisata. Kelembagaan Kepariwisataan adalah kesatuan unsur beserta mitranya yang dikembangkan secara terorganisasi, meliputi Pemerintah Desa, pelaku usaha, dan masyarakat, regulasi dan mekanisme operasional, yang secara berkesinambungan guna menghasilkan perubahan ke arah pencapaian tujuan di bidang Kepariwisataan. Pelatihan ini bertujuan agar pengelola Desa Wisata memahami manajemen kelembagaan kepariwisataan, baik struktur oorganisasi dengan segala kewenangannya dan tentunya sumber daya manusia pengelola desa wisata yang regeneratif dengan pendekatan Community Based Tourism (CBT).

Pengelola Desa wisata yang tumbuh tanpa proses pendidikan pariwisata berbasis wisata modern (kekinian) tentu memiliki banyak kendala dalam pelaksanaanya, namun pemahaman pengelolaan yang baik tersebut dapat dilakukan seiring perjalanan desa wisata yang ada, justru yang menjadi kemenarikan adalah pengelola desa wisata melakukan dengan rutinitas yang berkelanjutan, ikhlas berjuang sekaligus mempertahankan budaya yang dilaksanakan hingga kini. Namun untuk menjadi desa wisata yang maju dan mandiri, tentu membutuhkan manajemen pengelolaan yang baik sesuai dengan minat pengunjung, misalnya pentingnya kelembagaan yang berkaitan dengan promosi desa wisata (hubungan masyarakat), kepemanduan yang baik, pelayanan prima desa wisata, dan lainnya. Apalagi dalam pengelolaan desa wisata dengan pemberdayaan masyarakat lokal (CBT) tentu membutuhkan energi yang maksimal, pengelola desa wisata secara kelembagaan memiliki fungsi untuk memberdayakan masyarakat lokal dalam pengembangan desa wisata.

CBT merupakan konsep pengembangan suatu destinasi wisata melalui pemberdayaan masyarakat lokal, dimana masyarakat turut andil dalam perencanaan, pengelolaan, dan pemberiaan suara berupa keputusan dalam pembangunannnya. Ada tiga kegiatan pariwisata yang dapat mendukung konsep CBT yakni penjelajahan (adventure travel), wisata budaya (cultural tourism), ekowisata (ecotourism). CBT akan melibatkan pula masyarakat dalam proses pembuatan keputusan khususnya terkait dengan perolehan pendapatan, kesempatan kerja, serta pelestarian lingkungan dan budaya asli setempat yang pada akhirnya menumbuhkan jati diri dan rasa bangga dari penduduk setempat yang tumbuh akibat peningkatan kegiatan pariwisata. Konsep CBT juga merupakan implementasi ekonomi kerakyatan di sektor riil, yang langsung dilaksanakan dan dinikmati oleh masyarakat sendiri. Pengelola desa wisata dan masyarakat berperan aktif dalam kegiatan pengembangan desa wisata dari mulai perencanaan, implementasi, monitoring dan evaluasi. Hasil kegiatan desa wisata sebanyak mungkin dinikmati oleh masyarakat setempat. Jadi dalam hal ini masyarakat memiliki wewenang yang memadai untuk mengendalikan kegiatan desa wisata. Selain itu, dalam penguatan kelembagaan penting juga dilakukan Collaborative Governance, dimana pengembangan dan pengelolaan desa wisata adanya keterlibatan pemerintah desa, masyarakat dan dunia usaha secara berkelanjutan. Sinergitas ini sangat penting mengingat tiga stakeholder tersebut saling terkait, pemerintah desa sebagai garda terdepan dalam pengelolaan desa wisata melalui kebijakan dan fasilitasi anggaran, masyarakat sebagai pelaku utama pengelolaan desa wisata, dan dunia usaha yang mendukung aktivitas desa wisata dengan menghadirkan unit-unit usaha tertentu.

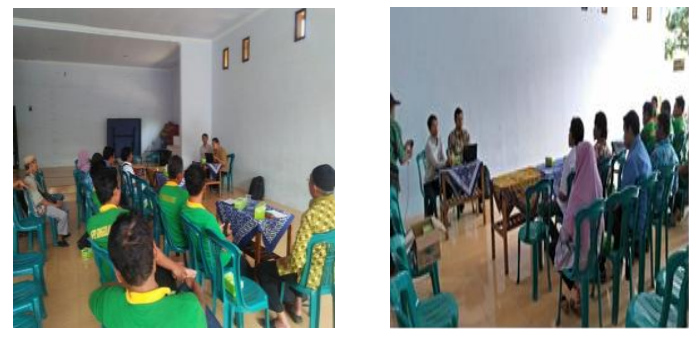

Gambar 2. Pelatihan Manajemen Kelembagaan Desa Wisata dan Community Based Tourism 


\section{Pelatihan Komunikasi Pariwisata, Komunikasi} Pemasaran dan "Branding Desa Wisata"

Pelatihan komunikasi pariwisata untuk mendesain model komunikasi pariwisata dan komunikasi Pemasaran Desa Wisata Tapak Tilas Sultan Agung. Pelatihan Komunikasi Pariwisata dan Pemasaran Desa Wisata menghadirkan narasumber Ibu Nita Andrianti, S.IP., M.A (Dosen dan Peneliti bidang Komunikasi Pariwisata). Sementara untuk pelatihan branding Desa Wisata dihadirkan narasumber Erwan Sudiwijaya, S.Sos., MBA (Dosen Ilmu Komunikasi UMY). Pelatihan ini menjadi sangat penting, karena komunikasi pariwisata merupakan modal utama dalam pengembangan desa wisata, komunikasi pariwisata berkembang dari menyatunya beberapa disiplin ilmu di dalam kajian komunikasi dan pariwisata. Kajian komunikasi pariwisata memiliki kedekatan biologis dengan kajian komunikasi dan pariwisata. Yang di mana komunikasi menyumbangkan teori komunikasi persuasif, komunikasi massa, interpersonal, dan kelompok. Sedangkan pariwisata menyumbangkan field kajian pemasaran pariwisata, destinasi pariwisata, aksesbilitas ke destinasi dan SDM serta kelembagaan pariwisata. Dalam konteks komunikasi bahwa manusia dan alam sekitarnya sendiri tidak bisa dipisahkan. Ketika memanfaatkan lingkungan, sebagai mahluk yang beradab, manusia sering beperilaku positif, kecuali dalam keadaan yang sangat terpaksa, manusia berperilaku negatif.

Perilaku positif yang ditunjukkan manusia dalam hubungannya dengan alam tersebut disebut perilaku yang berlandaskan kearifan lokal masyarakat (local wisdom) yang sudah ada di dalam kehidupan masyarakat secara turun-temurun. Perilaku positif dan nilai-nilai kearifan lokal terangkai dalam proses komunikasi yang baik melalui bingkai komunikasi pariwisata, dalam komunikasi pariwisata dibutuhkan berbagai model komunikasi, baik komunikasi interpersonal maupun komunikasi massa. Komunikasi interpersonal diperlukan untuk memahami pengunjung dari berbagai etnis dan mancanegara dengan sifat dan sikap yang berbeda, sehingga diperlukan untuk memahami perbedaan tersebut dengan melakukan pelayanan terbaik. Sementara komunikasi massa dalam bidang pariwisata tentu sangat dibutuhkan, hal ini tentu didasarkan pada kebutuhan utama desa wisata dalam melakukan promosi maupun kerjasama dengan media massa, sebab media massa merupakan faktor penggerak laju pertumbuhan desa wisata.

Sementara itu, pelatihan komunikasi pemasaran pariwisata diperlukan untuk menciptakan, mengkomunikasikan, mengenalkan dan menyampaikan produk wisata serta mengelola relasi dengan wisatawan untuk mengembangkan kepariwisataan dan seluruh pemangku kepentingannya. Produk wisata, misalnya watu goyang, budaya dan lainnya. Pelatihan komunikasi pariwisata ini dilengkapi dengan pemahaman branding desa wisata, Tujuan dari branding desa wisata ini akan berdampak bagi desa wisata agar memiliki satu identitas tersendiri yang membuat pengunjung dapat membentuk image terhadap desa wisata tersebut.
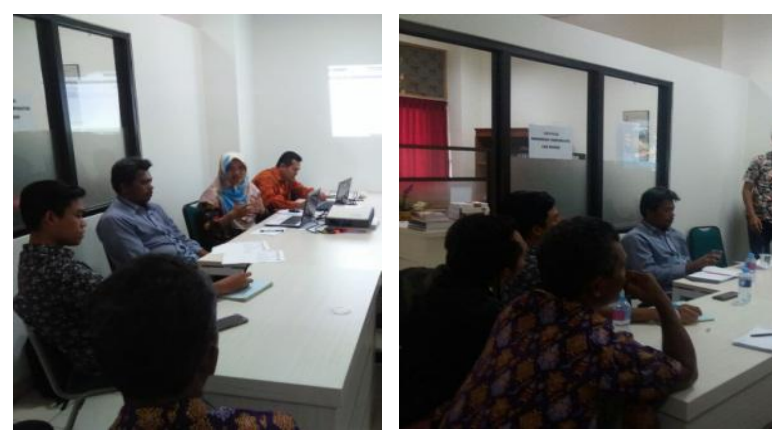

Gambar 3. Pelatihan Komunikasi Pariwisata, Komunikasi Pemasaran dan "Branding Desa Wisata

\section{Pelatihan Pelayanan Prima Desa Wisata}

Pelatihan pelayanan prima menghadirkan narasumber Bapak. Wartadi dari Jogja Tourism Training Center UGM, pelatihan pelayanan prima bagi Desa Wisata merupakan salah satu usaha yang dilakukan untuk melayani wisatawan yang datang di daya tarik wisata Tapak Tilas Sultan Agung (terutama Watu Goyang) dan menginap di Homestay dengan sebaik-baiknya, sehingga dapat memberikan kepuasan kepada wisatawan dan keinginan wisatawan, baik yang berupa produk barang atau jasa. Pelayanan prima adalah pelayanan terbaik yang diberikan Desa Wisata untuk memenuhi harapan dan kebutuhan wisatawan, baik wisatawan lokal, wisatawan nusantara, maupun mancanegara. Secara sederhana, pelayanan prima (excellent service) dapat diartikan sebagai suatu pelayanan yang terbaik dalam memenuhi harapan dan 
kebutuhan wisawatan. Pelatihan ini dilakukan agar dalam pengelolaan desa wiasta terdapat suatu pelayanan yang memenuhi standar kualitas. Pelayanan yang memenuhi standar kualitas adalah suatu pelayanan yang sesuai dengan harapan dan kepuasan pelanggan/masyarakat yang berkunjung.

Target kegiatan ini adalah pengelolaan desa wisata memenuhi dua elemen yang saling berkaitan, yaitu pelayanan dan kualitas. Kedua elemen tersebut sangat penting untuk dipahami oleh pengelola Dewi Dewi Tapak Tilas Sultan Agung. Kualitas pelayanan prima harus memiliki dimensi sebagai berikut:

a. Ketepatan waktu pelayanan berkaitan dengan waktu tunggu dan proses.

b. Kualitas pelayanan berkaitan dengan akurasi atau ketepatan pelayanan.

c. Kualitas pelayanan berkaitan dengan kesopanan dan keramahan.

d. Kualitas pelayanan berkaitan dengan tanggung jawab dalam penanganan keluhan pelanggan.

e. Kualitas pelayanan berkaitan dengan sedikit banyaknya petugas yang melayani serta fasilitas pendukung lainnya.

f. Kualitas pelayanan berkaitan dengan lokasi, ruangan tempat pelayanan, tempat parkir, ketersediaan informasi, dan petunjuk/panduan lainnya.

g. Kualitas pelayanan berhubungan dengan kondisi lingkungan, kebersihan, ruang tunggu, alat komunikasi, dan lain-lain.

Pelatihan diharapkan akan memberikan varian baru dalam atraksi wisata, dan akhirnya mampu memberikan manfaat ekonomi bagi pembangunan di tingkat desa dalam rangka mewujudkan kesejahterahaan masyarakat secara berkelanjutan. Pelatihan layanan prima ini diadakan atas dasar pentingnya mengembangkan salah satu faktor yang mendukung keberhasilan pengembangan desa wisata yaitu kualitas sumber daya manusia (SDM).

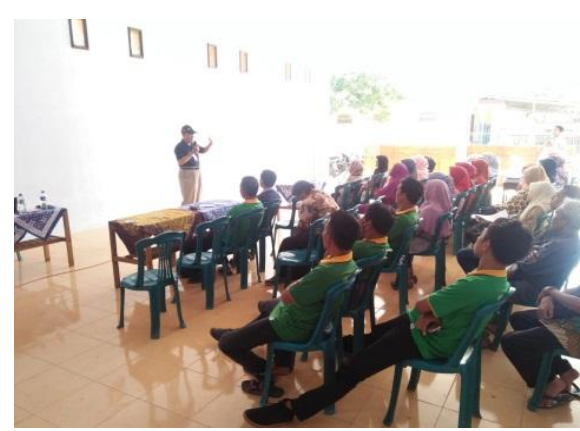

\section{Pelatihan Best Practice dan Studi Banding Pengelolaan Desa Wisata}

Studi banding dilakukan untuk memahami pengalaman terbaik (best practice) manajemen pengelolaan Desa Wisata yang memiliki potensi dan keunggulan yang sama dengan Dewi Tapak Tilas Sultan Agung Mangunan. Studi banding dilakukan di Desa Wisata Nglanggeran, Gunungkidul. Desa Wisata Nglanggeran merupakan percontohan desa wisata nasional dan memiliki prestasi dalam pengembangan desa wisata hingga berskala internasional. Selain di studi banding dilakukan di Desa Wisata Bleberan, Desa wisata Bleberan memiliki beberapa potensi wisata yang layak untuk dijadikan rujukan pengembangan desa wisata, antara lain wisata alam air terjun Sri Gethuk dengan tebing yang indah dan gua rancang kencana. Selain itu pengembangan Badan Usaha Milik Desa (BUMDes) yang berperan dalam pengembangan desa wisata ini sangatlah baik dan inovatif dengan pendapatan milyaran rupiah. Dalam studi banding ini juga dilakukan pelatihan best practice pengelolaan desa wisata oleh pengelola desa wisata Nglanggeran dan Bleberan.

Tujuan studi banding karena desa wisata tersebut memiliki potensi dan inovasi dalam pengelolaan desa wisata, yang lebih mengarahkan pada kualitas kunjungan wisatawan bukan kuantitas jumlah pengunjung. Fokus studi banding dilakukan berkaitan dengan manajemen pengelolaan kelembagaanpengelola desa wisata, maupun manajamen pengelolaan objek wisata. Beberapa hal yang menarik dari hasil pemaparan best practice dan kunjungan lapangan adalah penguatan pemahaman bagi Pengelola Dewi Tapak Tilas Sultan Agung, meliputi:

a. Pengelolaan Pariwisata berbasis masyarakat (CBT) 
yang selama ini dilakukan dan menjadi, yaitu: kepemilikan dan kepengurusan oleh masyarakat, kontribusi terhadap kesejahteraan sosial, kontribusi untuk menjaga dan meningkatkan kualitas lingkungan, mendorong terjadinya partisipasi interaktif antara masyarakat lokal dengan wisatawan, jasa perjalanan wisata dan pramuwisata yang berkualitas, dan kinerja friendly tour operator (FTO). Kunci sukses pengelola desa wisata adalah: niat tulus, pelibatan masyarakat, berbagi peran antara pengelola dengan masyarakat, ambil peluang dan evaluasi dan transparan.

b. Manajemen Desa Wisata berbasis Komunitas. Manajeman Desa Wisata dibawah pengelolaan masyarakat, awal proses pengembangan desa wisata memang membutuhkan pemahaman kesadaran masyarakat, bahkan dalam proses perjalanan waktu, masyarakat yang belum memiliki pemahaman wisata yang baik akan melakukan kritik terhadap desa wisata. Namun dalam memberdayakan masyarakat, membutuhkan kerja keras dan keikhalasan dan tentu tetap terus melibatnya masyarakat dalam berbagai momentum pengembangan desa wisata.

c. Potensi-potensi yang ada di dua wisata tersebut terus digali dan dilakukan inovasi sesuai dengan kebutuhan pasar wisatawan. Menggali dan melakukan inovasi potensi desa wisata tidaklah mudah, membutuhkan waktu, pemikiran yang fokus. Namun proses pengenalan potensi dan inovasi dapat dilakukan dengan seiring waktu perjalanan pengembangan desa wisata.

d. Memahami kewirausahaan sosial dan kewirausahaan budaya. Potensi usaha bersama masyarakat dan juga kebudayaan dan kearifan lokal diintegrasikan dengan kegiatan kepariwisataan ternyata bisa tumbuh dengan baik dan menggerakkan usaha ekonomi masyarakat, misalnya berkembanganya warung-warung yang menjajakan makanan khas desa wisata dan homestay.

e. Pengelolaan BUMDes. Pengelolaan desa wisata melalui Badan Usaha Milik Desa (BUM Des), dengan BUMDes ini pengelolaan keuangan desa wisata menjadi lebih baik, terukur dan transparan.
BUMDes dalam pengelolaan desa wisata ini memiliki pendapatan milyar-an pertahun, dan dari tahun ke tahun pendapatan semakin meningkat.
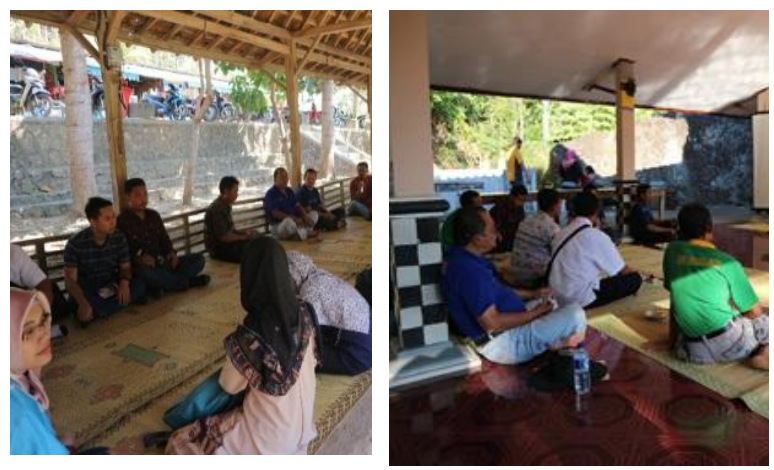

Gambar 5.

Pelatihan Best Practice di Desa Wisata Nglanggeran dan Desa Wisata Bleberan

\section{Penguatan Destinasi Desa Wisata}

Penguatan destinasi di Desa wisata Tapak Tilas Sultan Agung dilakukan dengan menambahkan wisata agro berupa pemberian bibit kopi, pemberian bibit kopi ini untuk melengkapi penguatan agrowisata di daya tarik wisata watu goyang, sehingga memperlihatkan nuansa agrowisata yang indah diatas bukit. Selain bibit kopi juga penyediaan papan informasi daya tarik wisata yang ditempatkan pada daya tarik wisata wayu goyang. Selain itu adalah fasilitasi legalisasi perkumpulan seni budaya dengan pembuatan akta notaris perkumpulan seni budaya.

\section{SIMPULAN}

Penguatan Kelembagaan dan Destinasi Desa Wisata Tapak Tilas Sultan Agung Mangunan dilakukan dengan melakukan pemetaan potensi unggulan daya tarik wisata melalui survei dan wawancara. Setelah dipetakan secara baik, tentu dilakukan penguatan berkaitan dengan kelembagaan dan sumber daya manusia pengelola desa wisata melalui berbagai pelatihan yang diselenggarakan, yaitu: pelatihan manajemen kelembagaan desa wisata dan community based tourism, pelatihan komunikasi pariwisata, komunikasi pemasaran dan "branding desa wisata", pelatihan pelayanan prima desa wisata, pelatihan best practice dan studi banding pengelolaan desa wisata ke Desa Wisata Nglanggeran dan Desa Wisata Bleberan. Selain itu, dilakukan penguatan destinasi di Desa 
wisata Tapak Tilas Sultan Agung dilakukan dengan menambahkan wisata agro berupa pemberian bibit kopi, penyediaan papan informasi daya tarik wisata yang ditempatkan pada daya tarik wisata wayu goyang, dan fasilitasi legalisasi perkumpulan seni budaya dengan pembuatan akta notaris.

\section{UCAPAN TERIMA KASIH}

Pada kesempatan ini, kami mengucapkan terimakasih kepada:

1. Kementerian Riset, Teknologi dan Pendidikan Tinggi Republik Indonesia, dengan skema Program Pengembangan Desa Mitra (PPDM) atas dukungan program dan anggaran yang diberikan.

2. Universitas Muhammadiyah Yogyakarta

3. Pemerintah Desa Mangunan, Dlingo, Bantul.

4. Kepala Dusun Cempluk, Desa Mangunan, Dlingo, Bantul.

5. Pengelola Desa Wisata Tapak Tilas Sultan Agung, Mangunan beserta masyarakat.

\section{DAFTAR PUSTAKA}

[1] Andini, Nurulitha., (2013), dalam "Pengorganisasian Komunitas Dalam Pengembangan Agrowisata di Desa Wisata Studi Kasus: Desa Wisata Kembangarum, Kabupaten Sleman, Jurnal Perencanaan Wilayah dan Kota, Vol. 24 No. 3, Desember.

[2] Juliantara, Dadang., (2003), Pembaharuan Desa, Bertumpu Pada Angka Terbawah, Lappera Pustaka Utama, Yogyakarta.

[3] Kuncoro, Hendrie Ajie, (2002) dan Janianton Damanik, Jurnal Ilmu Sosial dan Ilmu Politik Volume 6 No.1 Juli.

[4] Kusumasari, Bevaola, dan Hempri Suyatna,(2015) dalam "Peningkatan Kapabilitas Pemasaran Pascabencana Bagi Perempuan Hunian Tetap Pager Jurang, Sleman, Yogyakarta", Jurnal Indonesian Journal of Community Engagement Vol. 01. No. 01.

[5] Nadir, Sakinah.,(2013) dalam "Otonomi Daerah dan Desentralisasi Desa: Menuju Pemberdayaan Masyarakat Desa, Jurnal Politik Profetik Volume 1 Nomor 1.

[6] Widjajanti, Kesi, (2011) dalam "Model Pemberdayaan Masyarakat", Jurnal Ekonomi Pembangunan Volume 12, Nomor 1.

[7] Zanibar, Zen., (2007) dalam "Desa: Pergulatan Mencari Jati Diri”, Jurnal Konstitusi Volume 4,
Nomor 1. 